\title{
PENINGKATAN KOMPETENSI SISWA SD DENGAN PENDEKATAN MANJA (berMAiN, berkelompok dan tanya JAwab) TANJUNG DUREN SELATAN, GROGOL
}

\author{
Ferdinand Fassa $^{1}$, Ario Bintang Koesalawardi ${ }^{1}$, Andre Feliks Setiawan ${ }^{1}$ \\ ${ }^{1}$ Universitas Agung Podomoro
}

ferdinand.fassa@podomorouniversity.ac.id, ario.bintang@podomorouniversity.ac.id, andre.feliks@podomorouniversity.ac.id

\begin{abstract}
Abstrak
Momok mata pelajaran Sains dan Matematika telah menjadi permasalahan bagi siswa Sekolah Dasar. Metode pengajaran yang monoton terkadang menggangu penguasaan materi tentang konsep ilmu Sains dan menghambat munculnya kreativitas penguasaan. Permasalahan lainnya adalah mahalnya biaya bimbingan belajar yang ada di wilayah DKI Jakarta membuat sebagian masyarakat sulit untuk memperoleh pendidikan tambahan bagi anakanak yang ingin mendapatkan materi tambahan dalam pembelajaran seperti Sains dan Matematika. Peran lembaga bimbingan belajar dirasa masih sangat diperlukan untuk sebagian masyarakat mengingat materi kurikulum saat ini cukup banyak dan berat untuk diserap oleh sebagian siswa SD. Apabila di sekolah siswa mendapatkan waktu dan metode pengajaran yang kurang sesuai dari guru maka dapat mengakibatkan tingkat penguasaan materi ikut berkurang. Sehingga hal ini dapat mengakibatkan kompetensi dan nilai yang diperolehnya menjadi rendah. Berdasarkan kondisi tersebut, maka Program Studi Manajemen dan Rekayasa Konstruksi Universitas Agung Podomoro bermaksud untuk menyelenggarakan kegiatan peningkatan kompetensi melalui bimbingan belajar mata pelajaran Sains dengan judul: "Peningkatan Kompetensi Siswa SD dengan Pendekatan MANJA (berMAiN, berkelompok dan tanya JAwab) di wilayah Kelurahan Tanjung Duren Selatan, Grogol, Jakarta Barat.
\end{abstract}

Kata Kunci: Kompetensi Siswa SD, Bimbingan Belajar, RPTRA Amanah Bunda

\section{PENDAHULUAN}

Mata pelajaran seperti Bahasa Inggris Matematika, dan Ilmu Alam atau lebih dikenal Sains sering kali menjadi momok yang meyulitkan bagi sebagian siswa Sekolah Dasar (Fauziddin \& Mayasari, 2018). Secara khsusus mata pelajaran matematika dan Sains terkadang dikaitkan dengan kata "susah" oleh sebagian anak SD. Jika kita melihat kurikulum sekolah dasar saat ini, maka pelajaran Sains merupakan pelajaran yang berbicara mengenai fenomena alam dan kehidupan seharihari. Apabila pelajaran ini tidak diajarkan dengan metode yang pas dan menyenangkan maka dapat membuat siswa menjadi mudah stres dan pada akhirnya malas untuk belajar. Jika siswa SD merasa 
stres, maka dapat menurunkan motivasi mereka. Selain itu siswa yang mengalami kesulitan belajar matematika dan Sains juga mengalami tingkat kepercayaan diri yang kurang. Kemudian adanya kemudahan teknologi seperti telepon pintar (smartphone) yang seharusnya digunakan untuk mendukung proses pembelajaran siswa sebaliknya kebanyakan hanya digunakan untuk bermain game, sehingga memicu siswa untuk belajar mandiri menjadi berkurang. Faktor berikutnya adalah Metode pembelajaran Sains yang terdapat pada buku-buku pelajaran perlu dievaluasi kembali sehingga nantinya terdapat metode yang memberikan hal baru dan pada akhirnya dapat meningkatkan kompetensi siswa sekolah dasar (Anita, 2018). Seperti diketahui selama ini model pembelajaran yang berjalan dirasa kurang menyenangkan dan menarik bagi siswa-siswi SD. Kemudian metode pembelajaran yang dilakukan sangat monoton sehingga tidak memancing munculnya kreativitas siswa-siswi SD. Salah satu permasalahan yang sering ditemui dan terasa terasa sulit bagi para siswa adalah mata pelajaran Sains khususnya dalam hal penguasaan materi tentang konsep ilmu Sains.

Faktor lainnya yang menyebabkan mata pelajaran Sain dan Matematika sulit untuk dicerna karena masih ada sebagian guru yang belum memiliki cara dan metode yang sesuai untuk digunakan dalam proses pembelajaran. Untuk itu metode yang tepat dan sesuai dengan tingkat perkembangan anak harus dipilih dalam rangka meningkatkan mutu pendidikan. Metode pembelajaran yang bersifat menyenangkan dapat menjadi salah satu cara yang menarik agar siswa mampu menyerap dengan baik. Namun demikian suksesnya metode pembelajaran yang dipengaruhi oleh banyak faktor salah satunya adalah adanya minat dan motivasi.

Mata pelajaran Sains di tingkat Sekolah Dasar bertujuan untuk memperkenalkan kepada siswa dan siswi untuk memupuk rasa ingin tahu, mengembangkan kemampuan bertanya, mencari jawaban mengenai fenomena alam berdasarkan bukti, serta mengembangkan cara berpikir ilmiah. Selain itu pendidikan sains ditujukan untuk memupuk minat siswa sehingga dapat diaplikasikan dalam kehidupan sehari-hari siswa.
Pelajaran Sains dan Matematika juga bertujuan untuk mengajarkan dan melatih siswa dalam memecahkan masalah, melatih untuk berpikir kritis, melatih siswa dalam bersikap objektif, mampu bekerja sama, dan menghargai pendapat orang lain. Metode pembelajaran Sains sebaiknya meliputi: keterampilan mengamati atau dikenal dengan istilah observing, kemampuan dalam mengelompokkan, kemampuan dalam melakukan kegiatan pengukuran atau measuring, kemampuan dalam komunikasi, dan kemampuan dalam menarik kesimpulan atas fenomena yang ada.

Berdasarkan hasil pengamatan yang dilakukan oleh (Fauziddin \& Mayasari, 2018) didapat bahwa masih ada guru-guru yang menjelaskan mata pelajaran Sains menggunakan metode ceramah dan tanya jawab. Padahal metode ini masih dirasa kurang tepat apabila diterapkan pada anak kelas dengan usia anak antara 6-9 tahun (Fauziddin \& Mayasari, 2018). Temuan lainnya menyebutkan bahwa hasil pembelajaran mata pelajaran Sains/IPA pada sekolah dasar tergolong rendah. Hal ini disebabkan karena siswa-siswi kurang mampu mengaitkan antara materi yang diajarkan dengan situasi dunia nyata siswa atau dalam kehidupan sehari-hari (Anita, 2018).

Sehingga pada akhirnya metode yang digunakan mengakibatkan kurang efektif dalam proses pembelajaran. Adapun indikator keberhasilan yang dapat mengukur apakah proses pembelajaran yang telah dijalankan berhasil dapat dilihat saat siswa mengerjakan tugas. Hasilnya masih banyak ditemukan siswa yang mengalami kesulitan untuk menyelesaikan tugas yang diberikan. Hal ini disebabkan siswa kurang memahami apa yang disampaikan guru.

Agar siswa tidak tertinggal dan mampu mengikuti materi yang diberikan, banyak orangtua yang memberikan kelas tambahan dengan memasukan anaknya kedalam bimbingan belajar berbayar. Namun demikian biaya untuk kegiatan bimbingan belajar tidaklah murah apalagi di kota Jakarta. Hal ini tentu saja dapat memberatkan sebagian orangtua, khususnya masyarakat golongan berpenghasilan rendah. Sehingga pada akhirnya banyak siswa yang terus mengalami kendala dalam menyerap materi mata pelajaran Sain dan matematika. 
Berdasarkan atas hasil riset diatas, maka didapat 2 rumusan masalah yaitu: 1) Bagaimana memperkenalkan mata pelajaran Sains dan Matematika dengan pendekatan yang menyenangkan? 2) Bagaimana meningkatkan minat belajar siswa terhadap mata pelajaran Sains?

Untuk menjawab permasalahan tersebut maka Program Studi Manajemen dan Rekayasa Konstruksi Universitas Agung Podomoro menyelenggarakan kegiatan bimbingan belajar gratis khususnya mata pelajaran Sain dan Matematika. Tujuannya adalah untuk: 1) Meningkatkan minat belajar dan kompetensi siswa SD pada pelajaran Sains dan Matematika dengan metode pembelajaran yang mudah diserap oleh siswa; 2) Meningkatkan rasa ingin tahu terhadap permasalahan dan femomena alam; 3) Meningkatkan rasa percaya diri akibat pengetahuan yang bertambah. Adapun tema yang diambil pada kegiatan PKM ini mengangkat temal: "Peningkatan Kompetensi Siswa SD pada Mata Pelajaran Sains dan Matematika dengan Pendekatan MANJA (berMAiN, berkelompok dan tanya JAwab) wilayah Kelurahan Tanjung Duren Selatan, Grogol Jakarta Barat. Manfaat yang diharapkan pada kegiatan ini adalah agar siswa dapat meningkatkan kompetensi siswa SD dalam bidang mata pelajaran Sains. Selain itu dapat menumbuhkan keterampilan dalam bidang observasi dan kerjasama.

Kelompok masyarakat yang disasar terletak tidak jauh dari Universitas Agung Podomoro yaitu dengan radius $2 \mathrm{~km}$. Masyarakat yang disasar adalah masyarakat golongan yang dikategorikan sebagai masyarakat menengah bawah yang belum memiliki biaya untuk memberikan les tambahan kepada anak-anaknya.

Lokasi kegiatan yang dipilih terletak di daerah Kecamatan grogol Petamburan dengan luas wilayah sebesar 1.128,86 Ha yang terbagi dalam 7 kelurahan, 73 RW, dan 863 RT. Adapun keadaan masing-masing kelurahan di Kecamatan Grogol Petamburan diuraikan sebagai berikut: 1) Kelurahan Tanjung Duren Utara. Kelurahan Tanjung Duren Utara dengan luas wilayah 133,56 Ha terbagi dalam 7 RW dan 90 RT; 2) Kelurahan Tanjung Duren Selatan. Kelurahan Tanjung Duren Selatan dengan luas wilayah 176,90 Ha terbagi dalam 7 RW dan 91 RT; 3) Kelurahan Tomang. Kelurahan Tomang dengan luas wilayah 187,65 Ha terbagi dalam16 RW dan 174 RT; 4) Kelurahan Grogol. Kelurahan Grogol memiliki area terkecil dengan luas wilayah 122,48 Ha, Kelurahan Grogol terbagi dalam 10 RW dan 114 RT; 5) Kelurahan Jelambar. Kelurahan Jelambar dengan luas wilayah 144,47 Ha. Kelurahan Jelambar terbagi dalam 11 RW dan 138 RT; 6) Kelurahan Wijaya Kusuma. Kelurahan Wijaya Kusuma dengan luas wilayah 220,00 Ha merupakan kelurahan yang memiliki area paling luas di Kecamatan Grogol Petamburan. Kelurahan Wijaya Kusuma terbagi dalam $10 \mathrm{RW}$ dan $124 \mathrm{RT}$; 7) Kelurahan Jelambar Baru. Kelurahan Jelambar Baru dengan luas wilayah 14,38 Ha terbagi dalam 12 RW dan 132 RT.

Berdasarkan dari pemetaan wilayah di Kecamatan grogol diatas, maka dipilih satu wilayah untuk disurvey dan dijadikan lokasi kegiatan yiatu kelurahan Tanjung Duren Selatan. Pada tahap identifikasi awal, tim mendapatkan beberapa informasi yang dibutuhkan untuk pelaksanaan bimbingan belajar ini yaitu terdapat potensi kebutuhan yang salah satunya untuk meningkatkan minat belajar siswa terutama dibidang eksakta dan sains. Berdasarkan wawancara dengan ibu-ibu masyarakat setempat dikatakan bahwa, mereka kesulitan untuk mengajarkan mata pelajaran ini mengingat mereka tidak memiliki bakat dan kompetensi untuk memberikan pembelajaran seperti Sains dan Matematika.

Mereka juga mengeluhkan bahwa pelajaran anak sekarang berbeda jauh dibandingkan saat mereka bersekolah dulu, menurut mereka pelajaran SD saat ini seperti materi mereka saat mereka SMP dulu. Selain itu mereka juga tidak memiliki banyak waktu untuk mengajari anak-anaknya karena sebagian warnanya sibuk mengurusi rumah, sedangkan mereka juga memiliki keterbatasan biaya untuk memasukan anaknya mengikuti les atau bimbingan belajar.

Setelah mendapatkan banyak informasi mengenai masalah yang ada, tim PKM berdiskusi untuk memberikan ide-ide yang diperlukan untuk mengatasi permasalahan tersebut. Beberapa alternatif di paparkan oleh anggota tim beserta dengan mahasiswa yang ikut terlibat dalam kegiatan PKM ini. Solusi yang dipilih adalah dengan memberikan bimbingan belajar yang kreatif dan 
dikemas secara menyenangkan agar siswa mau ikut terlibat dalam PKM ini. Selain itu, Tim PKM meminta ijin kepada RT setempat untuk menggunakan fasilitas ruangan yang berada dikawasan tersebut yaitu aula RPTRA Amanah Bunda.

\section{METODE}

Untuk melaksanakan kegiatan ini, maka metode pelaksanaan dijabarkan dalam bentuk diagram alur. Berikut adalah metode pelaksanaan dalam menyelengarakan workshop ini, yaitu:

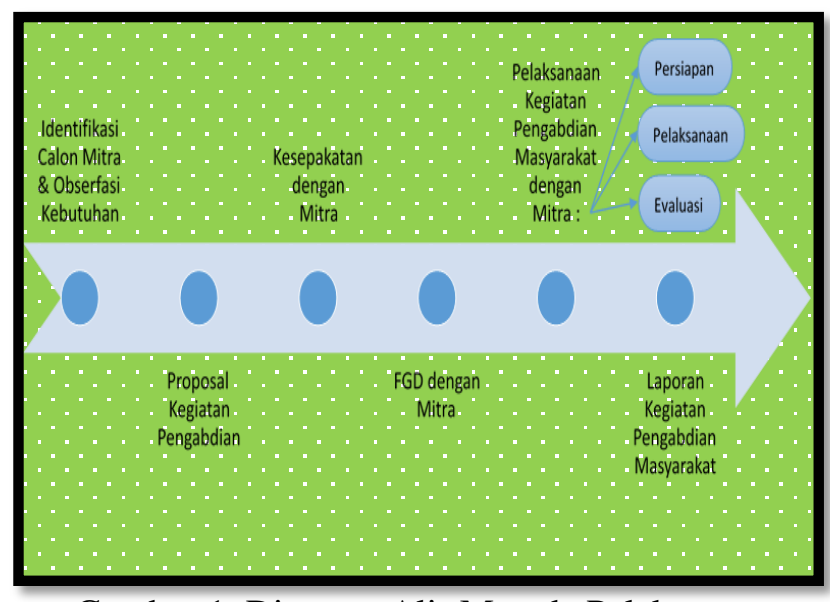

Gambar 1. Diagram Alir Metode Pelaksanaan

\section{Tahap Identifikasi dan Observasi}

Tim Pengabdian Kepada Masyarakat (PKM) Prodi MRK Universitas Agung Podomoro, mengunjungi wilayah Tanjung Duren Selatan tepatnya di Gang Manggis XIX Rt. 10 Rw. 04. dan melakukan diskusi dengan masyarakat untuk melakukan identifikasi (gambar 2) dan menyampaikan maksud dan tujuan kegiatan.

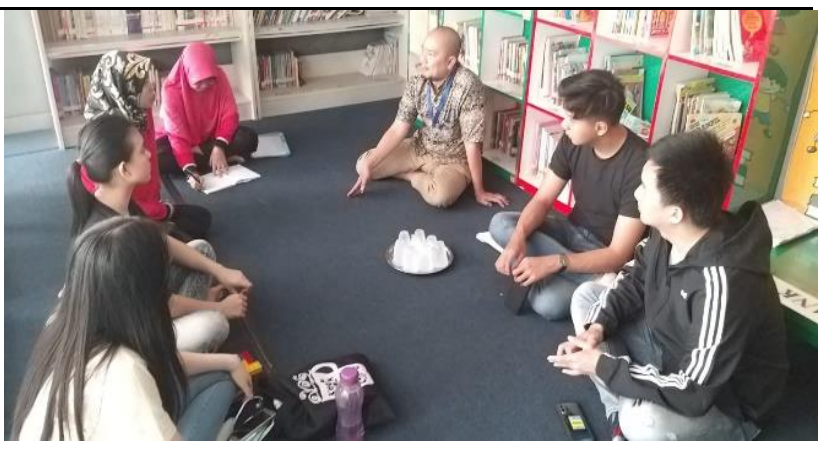

Gambar 2. Identifikasi Mitra

Pada diskusi dengan masyarakat tim PKM Prodi MRK UAP untuk mendapatkan kebutuhan yang diperlukan oleh masyarakat. Hasil dari diskusi dan identifikasi di dapat beberapa potensi kebutuhan antara lain: 1) Peningkatan minat belajar untuk siswa SD khususnya dibidang matematika, Bahasa inggris dan Sain; 2) Peningkatan pengetahuan tentang sampah plastik; 3) Peningkatan kreatifitas anak agar mereka tidak hanya bermain gadget, namun beraktifitas fisik dengan temantemannya. Dari beberapa potensi yang ada, maka tim PKM menampung untuk di diskusikan kembali di Prodi.

\section{Tahap Pembuatan Proposal}

Selanjutnya Ketua tim PKM membuat proposal, yang nantinya akan di diskusikan kembali kepada masyarakat untuk mendapatkan persetujuan mitra. Proses pembuatan proposal dilakukan 1 minggu. Tim PKM memilih 1 kegiatan dari 3 kegiatan yang telah diidentifikasi bersama mitra.

\section{Tahap Kesepakatan Mitra}

Tahap berikutnya, tim PKM kembali mendatangani masyarakat untuk memdapatkan persetujuan mengenai kegiatan yang mampu dilaksanakan oleh tim. Tim PKM memilih kegiatan peningkatan minat belajar untuk siswa SD untuk mata pelajaran IPA. Kemudian Tim PKM meminta persetujuan kepada perwakilan masyarakat agar mengenai kegiatan yang dipilih.

\section{Tahap FGD}

Tahapan FGD dilaksanakan untuk mendapatkan beberapa informasi seperti: 
mendata jumlah peserta yang akan mengikuti kegiatan. Pada FGD ini juga tim mengumpulkan informasi mengenai tempat pelaksanaan dan yang terpenting adalah waktu pelaksanaan.

\section{Tahap Pelaksanaan}

Setelah mendapatkan persetujuan jumlah peserta, waktu dan jadwal dari mitra, selanjutnya tim PKM menyiapkan kebutuhan yang diperlukan dalam kegiatan ini. Sebelum pelaksanaan Tim PKM melakukan persiapan berupa: 1) Persiapan kebutuhan alat, bahan dan materi yang akan digunakan; 2) Membeli alat dan bahan; 3) Menghitung jumlah anggaran biaya; 4) Mempersiapkan goodie bag yang akan dibagikan saat acara; 5) Mempersiapkan materi yang berisi: a) Penjelasan tentang latar belakang kegiatan; b) Pembagian masingmasing kelompok; c) Waktu yang digunakan dalam kegiatan ini. Setelah persiapan selesai, maka dilanjutkan dengan Pelaksanaan Acara.

\section{Tahap Pelaporan dan Evaluasi}

Tahap ini merupakan kegiatan untuk mengevaluasi hasil pelaksanaan PKM, ditahap ini juga tim akan membuat laporan akhir dan melakukan survei kepuasan dari peserta terhadap kegiatan ini.

\section{HASIL DAN PEMBAHASAN}

Pelaksanaan kegiatan Abdimas ini pada pertemuan sesi pertama diawali pada tanggal 13 November 2019. Pertemuan ini disambut dengan semangat yang tinggi dari siswa-siswa. Dari target awal yang direncanakan sebanyak 25 siswa, namun yang datang melebihi target yaitu sebanyak 31 siswa.

Pertemuan sesi pertama ini dibuka oleh koordinator mentor Steven dari prodi Manajemen dan Rekayasa Konstruksi angkatan 2019. Dosen selaku ketua pelaksana belum dapat hadir pada pertemuan pertama ini. Sesi pertama dimulai dari perkenalan kakak mahasiswa kepada siswa bimbingan yang didampingi oleh beberapa orang tua siswa dan koordinator Ruang Publik Terbuka Ramah Anak (RPTRA) yaitu ibu Iis Ambun.

Setelah perkenalan dilakukan satu persatu, kemudian kakak mahasiswa menjelaskan maksud kedatangannya yaitu untuk memberikan bimbingan belajar kepada siswa-siswa yang ada di sekitar area RPTRA, bimbingan belajar yang dimaksud difokuskan untuk mata pelajaran Sain dan Matematika, hal ini telah disampaikan sebelumnya kepada koordinator RPTRA Ibu Iis Ambun pada tahap identifikasi dan survey awal. Pengenalan sesi pertama (seperti terlihat pada gambar 3) dilaksanakan dengan cara membagi seluruh anakanak yang datang berdasarkan kelasnya, dimana apabila siswa kelas satu maka mereka wajib berkelompok di tingkat yang sama begitu seterusnya.

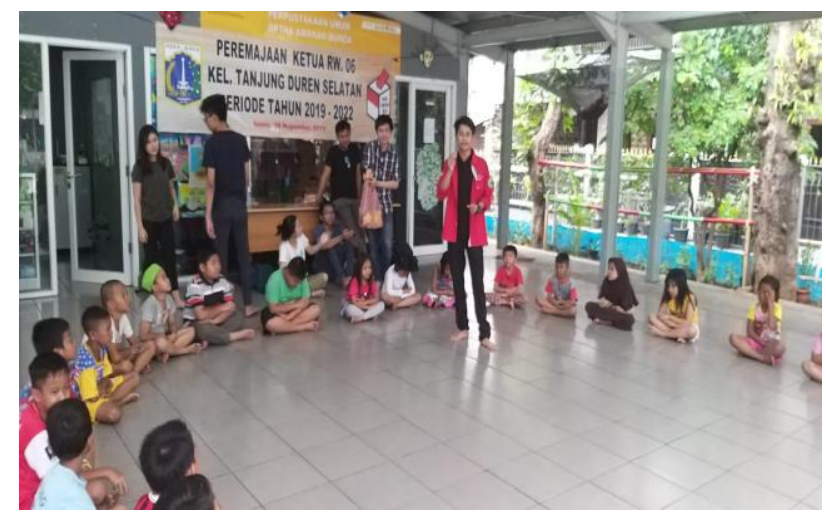

Gambar 3. Sesi Pengenalan

Berikutnya para kakak mahasiswa yang selanjutnya disebut mentor akan masuk kepada masing-masing kelompok, mulai dari kelompok kelas 1 hingga kelompok kelas 6. Setelah itu setiap mentor melakukan pendekatan dengan cara masingmasing agar hubungan kedekatan bisa terjalin terlebih dahulu yang gunanya memudahkan dalam penyampaikan materi. Pada pertemuan 1 ini juga setiap mentor membuat sesi permainan kecil maupun bernyanyi seperti terlihat pada gambar 4 . 


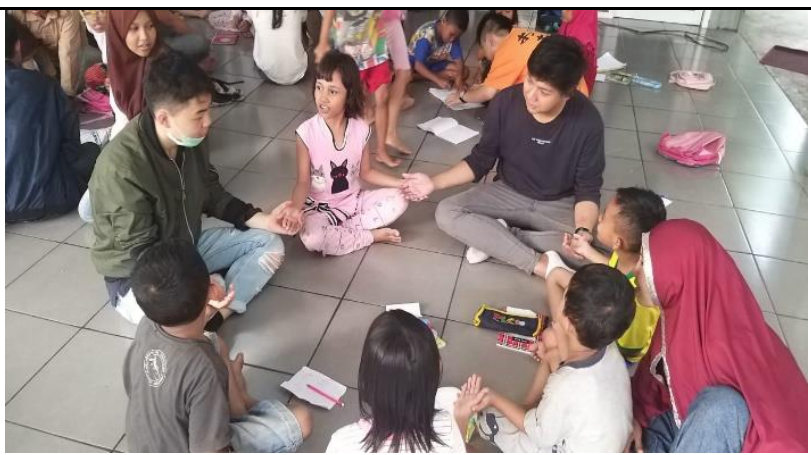

Gambar 4 Sesi Bermain Untuk Pendekatan ke Siswa

Pelaksanaan sesi kedua terlaksana pada tanggal 20 November 2019, pada sesi ini mentor abdimas membuka sesi kedua ini dengan perkenalan dosen selaku ketua pelaksana kegiatan ini seperti terlihat pada gambar 5 dosen atas nama Ferdinand melakukan dan memberikan tujuan pengenai pelaksanaan pengabdian masyarakat didepan siswasiswa kelas 1s.d kelas 6. Sesi kedua ini setiap kelompok yang telah dibagi mulai melakukan pembelajaran. Pembelajaran selama sesi 2 apabila merujuk kepada perencanaan maka pembelajaran difokuskan dibidang Ilmu Pengetahuan Alam (science). Namun pada pelaksanaanya bimbingan belajar yang dilaksanakan tidak hanya pada mata pelajaran IPA tetapi anaka-anak meminta untuk diajarkan mengenai mata pelajaran Matematika, Bahasa Inggris dan Bahasa Indonesia. Selain itu mereka juga banyak bertanya mengenai PR yang diberikan disekolahnya.

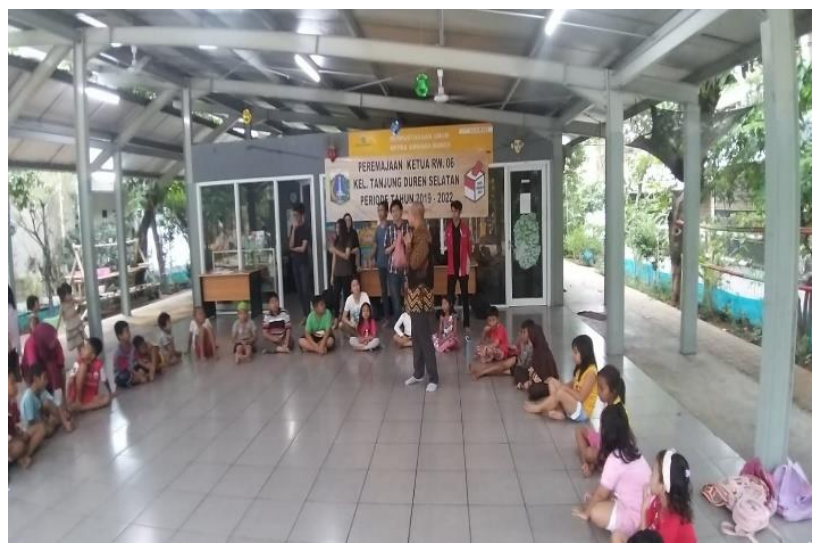

Gambar 5. Perkenalan Dosen
Pada sesi kedua salah satu kegiatan yang dilakukan adalah ketika mentor yang bernama Michael memberikan bimbingan untuk mata pelajaran Matematika berfokus pada perhitungan tambah maupun kurang (gambar 6).

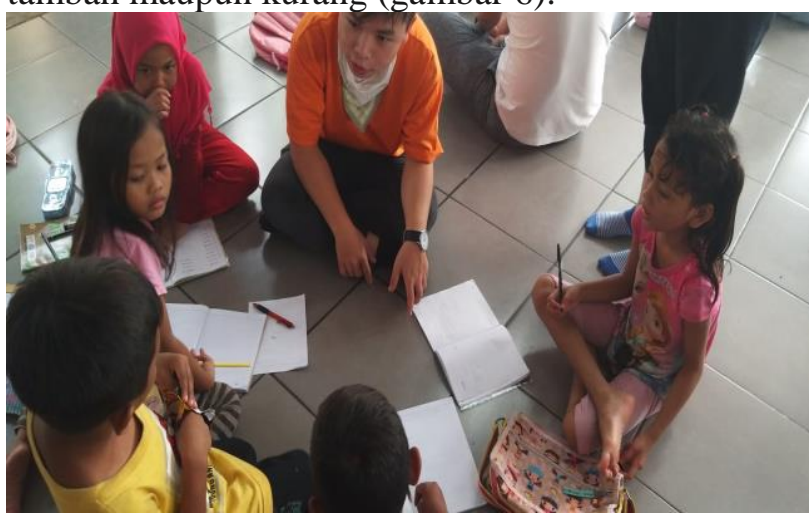

Gambar 6. Sesi Kedua Belajar Kelompok Suswa

Kelas 2

Pada pertemuan ketiga yaitu tanggal 27 November 2019, sesi berjalan sama seperti pertemuan 2. Namun di pertemuan ketiga ini juga tim abdimas akan memberikan hadiah untuk setiap anak-anak yang hadir. Isi hadiah terdiri dari buku tulis, penggaris, pensil dan penghapus. Di pertemuan ketiga juga peserta yang hadir lebih banyak jika dibandingan sesi sebelumnya, namun hal ini tidak menggangu jalannya kegiatan seperti terlihat pada gambar 7 .

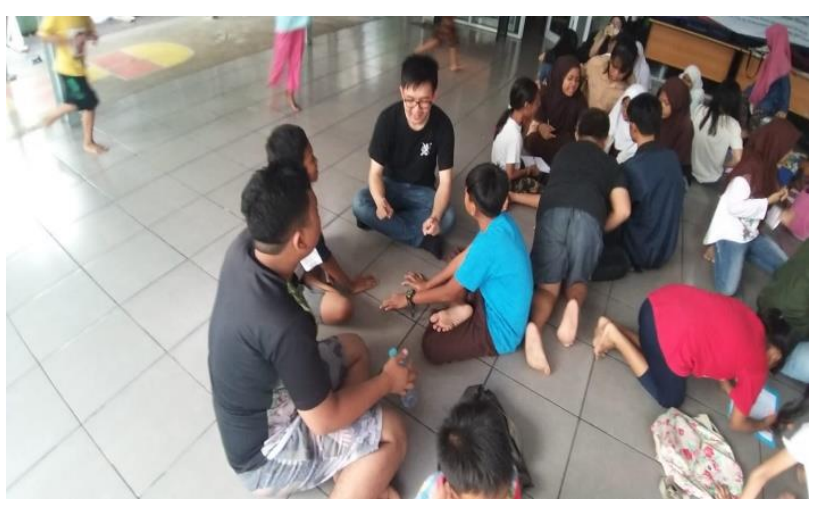

Gambar 7. Pertemuan Sesi 3

Pertemuan keempat merupakan pertemuan penutup dari kegiatan abdimas ini, pada pertemuan 4 dihadiri oleh seluruh tim dosen yang terlibat yaitu Bapak Andre Feliks 
(gambar 8), dan Bapak Ario Bintang (Gambar 9).

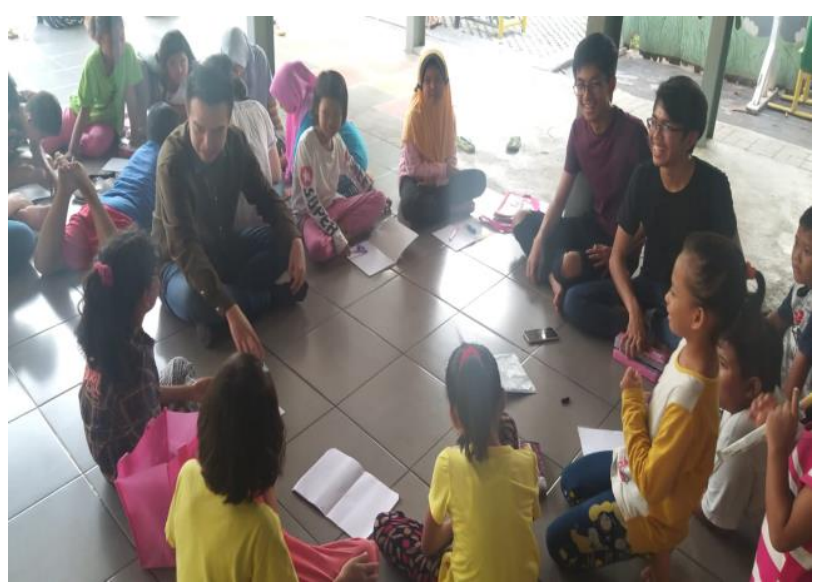

Gambar 8. Dosen Memberikan Materi Sain

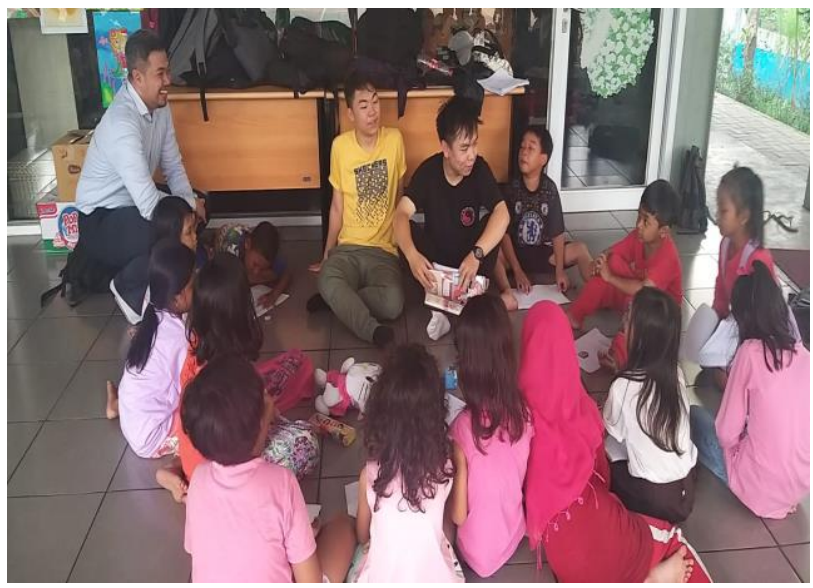

Gambar 9. Dosen Memberikan Materi Sains

Pertemuan keempat ini juga merupakan pertemuan puncak yang salah satu agendanya adalah sesi tanya jawab kepada anak-anak dan orang tua murid mengenai pelaksanaan kegiatan ini. Pertemuan puncak dihadiri oleh 48 anak-anak dari target 25 anak setiap minggunya.

Kegiatan abdimas yang diadakan pada tanggal 13 November sampai tanggal 4 Desember 2019 terdapat beberapa kendala yang awalnya menyulitkan mentor, adapun kendala yang ada yaitu: 1) Salah satu kendala yang dihadapi adalah menengenai kedatangan anak-anak ke lokasi bimbingan belajar, dimana berdasarkan hasil indentifikasi diawal dengan pihak koordinator, kegiatan ini seharusnya dimulai pada pukul 15.00 dan selesai pukul 17.00 namun pada pelaksanaannya kegiatan terkadang mundur sampai 15.45. Solusi yang dilakukan tim mentor abdimas tetap melaksanakan kegiatan bimbingan belajar dan menambah waktu belajar hingga selesai pukul 17.30 ; 2) Kendala lainnya adalah jumlah anak-anak yang selalu bertambah setiap pertemuannya. Berdasarkan proposal yang diberikan, kegiatan ini seharusnya dihadiri oleh 25 anak-anak pada setiap pertemuannya, namun seiring berjalannya waktu jumlah tersebut bertambah hingga pada sesi ke empat, jumlah yang hadir sebanyak 48 siswa. Bertambahnya peserta yang hadir merupakan efek positif mengenai kegiatan abdimas, solusi yang dilakukan tim mentor mengatur jumlah hadiah agar cukup untuk seluruh perserta. Selain itu tim mentor menambah mentor menjadi 2 khusus untuk kelompok yang jumlahnya banyak seperti pada kelompok kelas 2 dan kelas 3; 3) Umpan Balik (gambar 10), pada diskusi umpan balik dengan orang tua siswa, orang tua tidak mau berbicara di depan dengan alasan malu. Umpan balik berupa pernyataan kesan dari orang tua tetap dilakukan dengan wawancara, namun tidak dilakukan didepan anak-anak. Hasil umpan baliknya yang terpenting adalah mereka sangat puas denga kegiatan positif ini dan berharap agar tidak cepat berakhir.

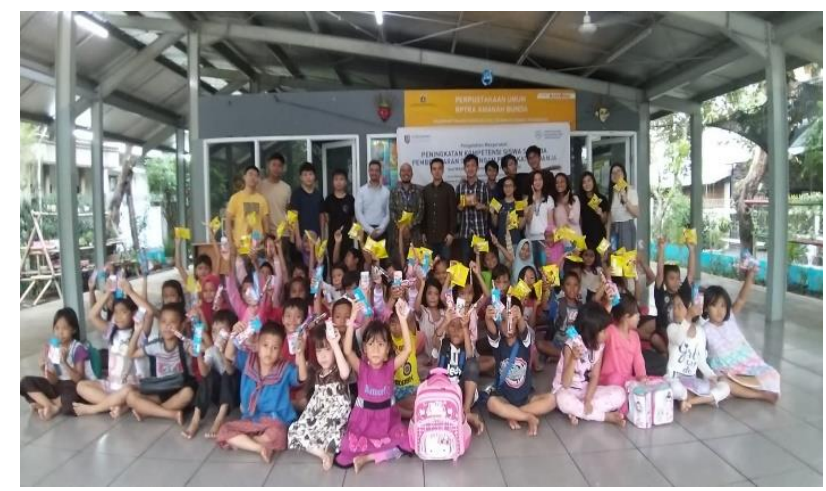




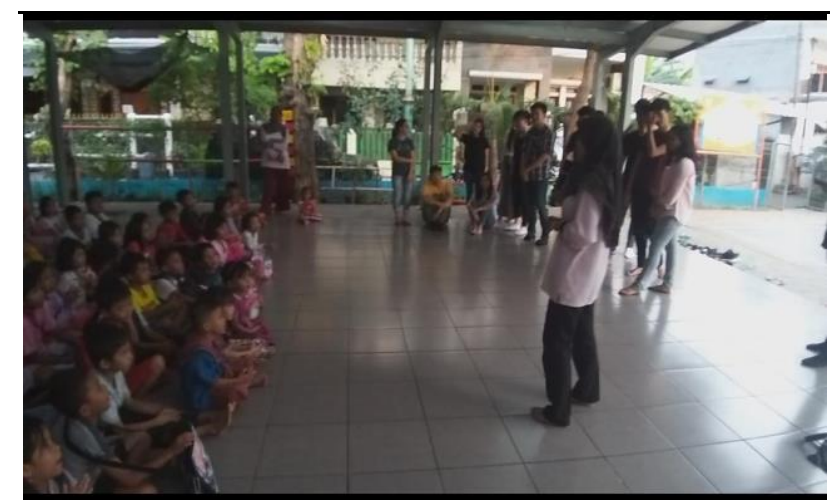

Gambar 10. Sesi Penutupan dan Umpan Balik

\section{KESIMPULAN}

Berdasarkan tujuan awal dari kegiatan Program Pengabdian Kepada Masyarakat ini dapat disimpulkan:

- Kegiatan bimbingan belajar ini sangat disenangi karena pembelajarannya santai dan asik sehingga meningkatkan minat belajar dan kompetensi siswa SD pada pelajaran IPA dengan metode pembelajaran yang mudah diserap oleh siswa.

- Anak-anak yang mulai mengerti tentang manfaat dari mata pelajaran IPA khususnya anak kelas 5 dan kelas 6.

- Bertambahnya Percaya diri siswa meningkat khususnya dalam hal belajar.

\section{UCAPAN TERIMAKASIH}

Ucapan terimakasih disampaikan kepada pengurus RPTRA Amanah Bunda Tanjung Duren Selatan yang telah mendukung dalam pelaksanaan kegiatan PKM ini sehingga dapat berjalan sesuai dengan baik.

\section{REFERENSI}

Anita, R. (2018). Upaya Meningkatkan Hasil Belajar Siswa Dalam Mata Pelajaran Ipa Melalui Model Pembelajaran Everyone Is Teacher Here Pada Siswa Kelas Iii Sdn 25 Carocok Anau. Jurnal Manajemen Pendidikan, 3(3), 557-566.

Fauziddin, M., \& Mayasari, D. (2018). Pemanfaatan Metode Picture And Picture Untuk Meningkatkan Hasil Belajar Siswa Kelas Rendah Di Sekolah Dasar. Jurnal Pendidikan Tambusai, 2(1), 264-274.

\section{(1)}

. 